\title{
WHERE THE FORESTER MEETS THE FARMER
}

\author{
R. A. Soundy \\ Whangaroa, N orthland
}

THE AREA of New Zealand is 26 million hectares of which 8.3 million hectares is classed as good farming land, 500000 ha as first-class cropping land, and 607000 ha as productive exotic forest, about half State owned and half owned by private companies or local authorities. Recently the rate of exotic forest planting has accelerated and the area being planted has expanded to a degree that could be termed an arboreal population explosion. The forester and the farmer are now meeting face to face and in some areas the meeting has become a confrontation. This paper outlines some of the economic and sociological problems that have arisen and the opinions expressed herein, as distinct from the facts and figures, are my own and not necessarily those of any other person or organization.

\section{THE CONFRONTATION}

Although many farmers viewed with regret the planting of undeveloped and reverted laad, which they would have preferred to have seen developed for farming, no real opposition was voiced. However, when large forestry concerns began buying up productive farms for planting in exotic timber, very great concern and alarm was expressed, especially in districts where the scale of acquisition became significant. The impact in some rural areas cannot be ignored, and in my opinion has implications for the whole country which should be examined, now.

THE ECONOMIC IMPACT

When several farm properties in a district are taken out of production, the market value and salability of the farms that remain are reduced. Farm servicing is curtailed - e.g., a stock firm finds that it can no longer justify an agent stationed in the district, the freezing works buyer vanishes, a local carrier goes out of business, the local store closes.

Forestry is big business and land purchase is not an item of great significance in the expense side of their accounts. While no business pays more than it needs for anything it purchases, forest companies are in the position to be able to make immediate and attractive cash offers for land they wish to acquire. Most would- 
be farmer buyers, however, have a time-consuming exercise to arrange finance. This situation has frequently caused resentment among neighbouring farmers, particularly younger men on properties barely large enough to be economic units by May's standards, and who wish to enlarge or increase, their holdings.

A survey of the situation in Waikato and north King Country, carried out in August, 1974, revealed the following facts.

In the Waitomo County, a total of 12000 ha has been sold or leased to forestry (State forest and private companies). While this figure includes reverted or undeveloped land, there have been sales of productive farm land which have caused very great concern to farmers and local bodies in these areas. For example, a property of 360 ha, 200 ha in grass with the balance cutover bush, was sold for forestry. This property, along with three neighbouring farms, was developed by the Lands and Survey Department at the taxpayers' expense and settled as ballot farms in 1963-4. This farm could be resettled to a young farmer, with a development loan to increase the grassed area or, alternatively, amalgamated into the three remaining farms.

Similarly, 490 ha sold for $\$ 80000$. This property was not well farmed but had a considerble area of flat land and was described as an "ideal economic unit for an energetic young farmer". It was situated $8 \mathrm{~km}$ from rail, $27 \mathrm{~km}$ from Te Kuiti and $225 \mathrm{~km}$ from the port of New Plymouth. The purchasing company is quoted as stating that it intends establishing a forest in this area, and its long-term plans envisage acquisition of a substantial area of land for planting. Farmers of the district appealed against the sale in the Supreme Court, Hamilton in December, 1973, on the grounds that a young farmer in the district had a verbal agresment to purchase at the same price, and was currently arranging finance. The Court turned down the farmers' application to deny the sale to the forestry company, although the Judge was sympathetic to the problems that the sale would create for the locals. Settlers then approached the Minister of Lands in March, 1974, asking that the Crown appeal to the Supreme Court but, according to Crown counsel, in this case the Crown had no right of appeal under section 26 of the Land Values Proceedings Act 1948.

Also in the Cambridge area, 80 ha of flat land sold at $\$ 5500 /$ ha and 47 ha of flat land sold for $\$ 4250 /$ ha. These properties were carrying 15 to 17 stock units/ha and the prices padd were $\$ 1250$ to $\$ 1500$ above the going rate. It is understood that the land will be used for nurseries. 
Further, in South Waikato, other all-grass farm's have been sold for forestry. At Lichfield, 200 ha sold for $\$ 165000$, and at Wiltsdown an unknown area sold for $\$ 750$ ha, while at Putaruru an offer of $\$ 195000$ was made for $224 /$ ha. At Whakamaru, three adjoining farms totalling approximately 500 ha sold for $\$ 375 /$ ha. As these farms sold 20 ha of homestead and buildings separately, the total return to the vendors would be approximately $\$ 500 /$ ha. The pasture has been destroyed in preparation for tree planting.

\section{THE SOCIOLOGICAL IMPACT}

When several properties, usually contiguous, in a district are sold to forestry, there is a further contribution to the rural population drop, already a matter of serious concern in many country areas. School rolls fall, school bus services are curtailed, community organizations are weakened and all the old familiar symptoms that we have experienced in the past are with us again.

This deals a strong psychological blow to the farmers who remain and the dwindling remnants of the people who have serviced them. That peculiar quality we call the "rural way of life" suffers and morale falls. I have heard more than oae farmer say, bitterly, "Who wants to be farming on his own in the middle of a pine forest?"

\section{THE WIDER IMPLICATIONS}

From 1949 to 1964,15800 ha of farming land was lost to urban expansion and it is estimated (N.Z. Yew Book, 1974) that, by 1984 , a further 30000 ha will be required. With certain outstanding exceptions, cities are not usually built on rugged, steep, low-producing country, and it is safe to assume that these areas would comprise mainly highly productive farming land.

If the trend of sale of productive, easy contoured, developed farming land to forestry continues, and possibly accelerates, can the nation 'afford to retire a significant area of good grasslands?

At the moment, the meat and wool industry is facing a severe recession, but no one seriously expects this to be a long-term affair, and I would predict that we will shortly, once 'again, be faced with markets that we are unable to fill.

To me, as a farmer, it was sickening to stand on a vantage point and see 480 ha of clean, easy contoured grassland that had been carrying 12 to 15 stock units/ha, systematically destroyed so that the area could become yet another pine forest. Surely, none of us who has spent years trying to produce better grass- 
land could view such a scene without a feeling of deep anxiety if this trend continues.

\section{GUIDELINES FOR THE FUTURE}

I submit that forestry and farming are not incompatible and that a state of peaceful co-existence is possible, to the benefit of both industries.

One local body (Waitomo County Council) has approached the executive of the N.Z. Counties Association, asking that Government be approached to:

(1) Restrict, forthwith, the sale of all viable farming properties and developed grasslands to forestry companies, and

(2) Amend the Land Sales Act to enable the Crown to oppose transfer of farm land to forestry where such action is considered warranted, having regard to public interest and the interests of the surrounding areas.

I feel that to restrict by legislation, to this extent, the expansion of any industry, is distasteful to most New Zealanders, and could be a dangerous precedent. We must also be careful not to restrict the right of a farmer, or any property owner, to sell his property to whom he chooses. Nevertheless, I do feel that some delaying procedure should be set up, where it can be shown that a viable economic farming unit may be purchased for farming purposes at a competitive figure. Also, I believe that the Crown should have the right to intervene, or at least to appeal, in cases such as that quoted earlier in this paper.

I regard as constructive a Federated Farmers' suggestion that the Crown be Basked to purchase suitable farm land such as that being negotiated by forestry interests and to settle suitable young men, with financial assistance to develop the land sufficiently for stock farming.

I believe that the running of livestock in conjunction with forestry has a potential that can be developed and is., as yet, in its infancy. I would urge that research on this technique be intensified, and that trials be undertaken on farming properties to explore the feasibility of this practice on a large scale. Unfortunately, I da not think that the large forestry concerns are really interested in this form of diversification.

Finally, I submit that we have a hungry world to feed, and that it is long-term folly not to utilize every worthwhile hectare of productive grassland or cropping lend. We can profitably plant many more millions of trees without doing so at the expense of land that produces food. 